\title{
Self-Regulated Learning for New Tertiary Students in the Bachelor of Psychology Degree Course
}

\author{
Gianto Raymond Hia, Miryam Wedyaswari, and Sarah Aurelia Saragih \\ Faculty of Psychology \\ Universitas Padjadjaran
}

\begin{abstract}
The transition from senior high-school to university is an important phase for new tertiary students to which they must adapt, particularly in academic matters. This study was conducted with new students $(n=95)$, commencing studies in 2017 at the Faculty of Psychology, Universitas Padjadjaran, Bandung, West Java, to obtain a picture of their abilities in self-regulated learning. The Bachelor of Psychology course, which is a Science subject, involves a great deal of social science, and so requires a unique study strategy, to enable new students to adapt in the academic field. This study utilized the Motivation Strategy Learning Questionnaire (MSLQ) measurement instrument scale, supplemented by a survey questionnaire regarding academic results. Some 70\% of new tertiary students in the Bachelor of Psychology (BPsych) course organized their goals and regulated their motivation internally (internal goal motivation). The study strategy most used to regulate their cognition was elaboration, whilst there still tended to be a few who capitalized upon peer learning and critical thinking strategies in their learning processes $(40 \%)$. The aspects of effort regulation and help seeking were found to be able somewhat to predict their Student Achievement Index (Indeks Prestasi Siswa-IPS). For this reason, the learning environment needs to be conditioned so that these two aspects are facilitated optimally.
\end{abstract}

Keywords: motivation, learning strategies, MSLQ, new tertiary students, psychology

Transisi dari SMA ke perkuliahan merupakan masa yang penting bagi mahasiswa baru untuk beradaptasi khususnya di bidang akademik. Studi ini dilakukan pada mahasiswa baru Fakultas Psikologi Universitas Padjadjaran angkatan $2017(n=95)$ untuk mendapatkan gambaran kemampuan self-regulated learning. Program studi psikologi yang merupakan jurusan IPA, banyak mempelajari ilmu sosial sehingga diperlukan strategi belajar yang unik untuk membantu mahasiswa barunya dalam beradaptasi di bidang akademik. Studi ini menggunakan skala pengukuran MSLQ (Motivation Strategy Learning Questionnaire) dan tambahan pertanyaan survei mengenai hasil akademik melalui kuesioner. Sebanyak $70 \%$ mahasiswa baru program studi psikologi menyusun tujuan dan meregulasi motivasinya secara internal (internal goal motivation). Strategi belajar yang banyak digunakan untuk meregulasi kognisi mereka adalah elaboration serta masih cenderung sedikit mahasiswa baru yang memanfaatkan strategi peer learning dan critical thinking dalam proses belajarnya (40\%). Aspek effort regulation dan help seeking ditemukan dapat sedikit memrediksi indeks prestasi siswa. Oleh karena itu, lingkungan belajar perlu dikondisikan agar kedua aspek ini terfasilitasi secara optimal.

Kata kunci: motivasi, strategi belajar, MSLQ, mahasiswa baru, psikologi

Every new tertiary student surely faces a period of transition, from senior high-school to university, in the first year of tertiary study (Irfan \& Suprapti, 2014). University is a higher level of education, compared to primary and secondary schooling, because, at university level, students are supplied a form of education which is more complex but more theoretically spe-

Correspondence concerning this article should be addressed to Gianto Raymond Hia, Faculty of Psychology Universitas Padjadjaran, Jatinangor, Sumedang. E-mail: raymond.gianto@yahoo.com cific. They must have the ability to decide something in a weighty work context, and have a responsibility for self-development, in a more professional direction, so as to become employment-ready graduates (Schneider $\&$ Preckel, 2017). It is these stressors which the students experience, which make it necessary for them to be able to adapt their learning styles in tertiary institutes of learning, and reduce the residual trial and error process, in seeking a strategic learning pattern, in line with their own ability. These stressors can in- 
fluence the academic achievements of new tertiary students, to the extent that there are two groups of academic achievement factors influencing them, those internal and those external. The external factors include socio-economic status, style of upbringing, and the number of stressors the individual suffers, whilst the internal factors include individual ability, evaluation of assignments, individual attitude towards the tertiary educational institute the student has chosen, hopes for the success he or she will attain, cognitive strategy and self-organisation (Clemons, 2008).

These academic stressors can be managed through certain learning approaches. Learning approaches can significantly influence academic achievement, because it is required that students are able to manage the internal and external factors which may influence their achievements. Research conducted by Fasikhah and Fatimah (2013) showed that the self-regulated learning approach was significantly influential over the achievement index of 54 tertiary students, who were given training in the use of self-regulated learning methods as their learning approach.

The self-regulated learning (SRL) approach is one of those suitable for use by tertiary students (Dörrenbächer \& Perels, 2016; Fabriz, Ewijk, Poarch, \& Büttner, 2014). The SRL process encompasses determination of goals, planning, supervision, organization and the evaluation of the learning process being practiced by the individual concerned (Pintrich, 2000). Self-regulated learning comprises four principle regulated aspects, such as cognition, motivation and effects, behavior, and context (environment). These four aspects are regulated throughout the SRL process, and can become the mediator in influencing academic achievement (Pintrich, 2004).

Regulation of the aspect of cognition comprises the use of cognitive and meta-cognitive strategies. Cognitive and meta-cognitive strategies are the individual awareness and ability of the student to use his or her knowledge when required, and control cognitive processes (Ö̈zsoy \& Ataman, 2009). This strategy comprises of repetition, elaboration, organization, critical thinking and self-control. Victor (2004, as cited in Özsoy \& Ataman, 2009) explained that, for a tertiary student, having good cognitive and meta-cognitive ability correlates with having high-level problem-solving abilities, particularly when studying new material. A tertiary student who has a good IPS has an understanding of his or her own cognitive ability, so as to be able to organize and control the steps which he or she must take to be able to study new material. However, cognitive strategy is not the only variable which is signi- ficantly influential (Garrett, Mazzocco, \& Baker, 2006).

The regulation of the aspects of motivation comprises the manner in which the individual determines goals, clarifies the tasks given during the learning process, considers the learning results achieved, and conceives of his or her own ability. The first component of motivation, proven to be able to influence academic achievement, is self-efficacy (Chemers, Hu, \& Garcia, 2001; Valentine, DuBois, \& Cooper, 2004; Zajacova, Lynch, \& Espenshade, 2005). Previous studies also succeeded in proving that good academic performance is commensurate with an increase in self-confidence. Self-confidence (self-efficacy) supports students to become bolder in facing new, more difficult challenges (Zimmerman \& Kitsantas, 2005; Komarraju \& Nadler, 2013). The second component, regulation of the affective component, comprises the management of a number of different emotions and feelings involved in the learning process. According to Rana \& Mahmood (2010), these feelings have both positive and negative impacts on the academic achievement of a person. Anxiety may have a positive impact if used as motivation, but will have a negative impact if the student becomes unproductive, and focuses only on the fear that he or she will fail in an examination. The third component is value (Pintrich, 1991). Value focuses on 'why students learn'. According to Duncan and McKeachie (2005), there are three factors which drive students motivation to learn: intrinsic goal (focus on mastery learning); extrinsic goal (focus on academic grade and approval from others); and task value (evaluation about how interesting, advantageous, and precious the academic task is).

The regulation of the aspects of behavior and context (environment) comprises resource management strategy. Resource management strategy is the strategy of an individual to manage the external resources he or she has, such as time and friends, as well as internal resources, in the form of personal endeavor. (Komarraju \& Nadler, 2013). The study conducted by Fasikhah (2013) found that the resource management strategy of an individual depends upon how that individual perceives his or her environment. A person who prefers to be alone will tend not to ask for the assistance of others in the learning process, and this causes such a person to be deficient in the desire to learn together with friends. Komarraju and Nadler (2013) found that this strategy is not a stand-alone variable, but is one supported by self-efficacy, which can predict the academic achievements of a person.

Studies in the field of self-regulated learning (SRL) stresses the analytical approach. What is meant by taking an analytical approach is that several aspects and 
processes need to be observed, one by one, so that later on one can conclude how the SRL process proceeds, for a person or a population (Pintrich, 2004). Self-regulated learning studies is also recommended to be conducted on a more specific population, for instance on the students in one faculty, one field of study, indeed one subject. This is because variations in the implementation of SRL will be of varied types, dependent upon the characteristics of the learning taking place (Credé \& Phillips, 2011; Pintrich, 2004). For this reason, in this study, the authors focused upon Psychology Course Programmes.

Psychology Course Programmes have unique learning materials. Psychology students belong to the Ilmu Pengetahuan Alam (Natural Sciences - IPA) School. IPA School students are accustomed to learn about the natural sciences and to face objective learning variables. Psychology learning materials comprise a number of materials which must be understood theoretically, and tend to concern occurring social phenomena. Practicums are occasionally conducted to strengthen understanding of human behavior, and the mental process behind it. In psychology, the learning materials require students to engage in a large amount of reading, to understand different kinds of theories and perspectives, and to be able to explain social phenomena, or social behavior, from a number of perspectives. Therefore, students will be faced with situations where "there is no sure or absolute answer," which is very much opposite to the learning process they experienced in senior high-school. It is with this phenomenon that ability in self-regulated learning is required, so that it was this which attracted the authors further to explore this ability, with new psychology course students. Based upon the explanation above, the study questions were: (1) what is the potential for the ability to engage in selfregulated learning, for new students of the psychology course, and; (2) how does this self-regulated learning ability play a role in the academic achievement of such new students?

\section{Method}

\section{Characteristics of the Participants}

The subjects in this study were tertiary students commencing their BPsych programmes in $2017(n=95$; $76.8 \%$ female). The selection of subjects was conducted using the accidental sampling technique, and was voluntarily undertaken on the part of the subjects. They were contacted via the social media LINE and Whats-
App, and asked to fill in a questionnaire based on Internet Google Forms.

\section{Research Design}

This study utilized a quantitative descriptive approach to describe the ability in self-regulated learning of new tertiary students in the Psychology study programme.

\section{Measurement Instruments}

Motivated Strategies for Learning Questionnaire (MSLQ). The authors used the Motivated Strategies for Learning Questionnaire (MSLQ) (Pintrich, 1991), as the measurement instrument for depicting the potential ability for self-regulated learning in the students. The process of adapting the questionnaire was performed through the stages of backwards and forwards translation, expert review, and try out. Several items in the questionnaire were altered by the authors, in order to bring them into line with the context and the subjects of the study. The MSLQ consists of 81 items, portraying ability to regulate the cognitive, motivational, affective, behavioral, and environmental aspects of the students in the learning process. The students completed the questionnaires, which used a 1- to 7-point Likert scale, where 1 equaled 'very inappropriate' and 7 equaled 'very appropriate', to the situation of the individual subject. In regards to the reliability of this measurement instrument, it was .921 (measured using the Cronbach's Alpha test). The instrument is illustrated in Table 1.

Academic achievement. The authors used the IPS received by the subjects in Semester 1 as their academic accomplishments. The authors then entered the questions about the IPS for Semester 1 into the measurement instrument, and also those obtained through unstructured interviews. The IPS data was aimed at enabling a view of the roles of aspects of self-regulated learning, regarding academic achievements. These student achievement indexes (IPS) were measured based upon the accumulations of grades obtained by the respondents, in all subjects studied in Semester 1, and had a standardized marking system, determined by the institution.

\section{Data Analysis}

Descriptive testing was conducted to determine the Means and the Standard Deviations of each aspect of self-regulated learning. This analysis was conducted to portray the potential ability in self-regulated learn- 
Table 1

Illustration of the MSLQ Measurement Instrument

\begin{tabular}{|c|c|c|c|}
\hline Regulation & & Aspects & Item (examples) \\
\hline $\begin{array}{l}\text { Regulation } \\
\text { of } \\
\text { Cognition }\end{array}$ & $\begin{array}{l}\text { Cognitive \& } \\
\text { Meta-cognitive } \\
\text { Learning } \\
\text { Strategies } \\
\text { (29 items) }\end{array}$ & $\begin{array}{l}\text { Rehearsal } \\
\text { Organization } \\
\text { Elaboration } \\
\text { Meta-cognitive strategy } \\
\text { Critical Thinking }\end{array}$ & $\begin{array}{r}\text { "When I study for this class, I practice saying the } \\
\text { material to myself over and over. When learning } \\
\text { university course material, I read it rigorously." } \\
\text { "When reading for this course, I make up questions to } \\
\text { help focus my reading. When reading university } \\
\text { course material, I construct questions capable of } \\
\text { making it easier for me." }\end{array}$ \\
\hline \multirow{3}{*}{$\begin{array}{l}\text { Regulation } \\
\text { of } \\
\text { Motivation } \\
\& \text { Affect }\end{array}$} & $\begin{array}{l}\text { Value } \\
\text { Components } \\
\text { (16 items) }\end{array}$ & $\begin{array}{l}\text { Intrinsic Goal Motivation } \\
\text { Extrinsic Goal Motivation } \\
\text { Task Value }\end{array}$ & $\begin{array}{l}\text { "In a class like this, I prefer course material that really } \\
\text { challenges me so I can learn new things. I prefer } \\
\text { university course material which teaches new things." } \\
\text { "The most important thing for me right now is } \\
\text { improving my overall grade point average, so my } \\
\text { main concern in this class is getting a good grade. The } \\
\text { important thing for me is getting good grades." }\end{array}$ \\
\hline & $\begin{array}{l}\text { Expectancy } \\
\text { Components } \\
\text { (12 items) }\end{array}$ & $\begin{array}{l}\text { Self-efficacy } \\
\text { Belief control }\end{array}$ & $\begin{array}{l}\text { "If I try hard enough, then I will understand the course } \\
\text { material. If I work hard enough, I will easily } \\
\text { understand material from this course." } \\
\text { "It is my own fault if I don't learn the material in this } \\
\text { course. It's my fault, if I don't study the course material." }\end{array}$ \\
\hline & $\begin{array}{l}\text { Affective } \\
\text { Components } \\
(5 \text { items })\end{array}$ & Test Anxiety & $\begin{array}{l}\text { "When I take a test I think about items on other parts } \\
\text { of the test I can't answer. When about to sit an exam, I } \\
\text { think about questions which I am unable to answer." }\end{array}$ \\
\hline $\begin{array}{l}\text { Regulation } \\
\text { of } \\
\text { Behavior }\end{array}$ & \multirow{2}{*}{$\begin{array}{l}\text { Resource } \\
\text { Management } \\
\text { Strategy } \\
\text { (19 items) }\end{array}$} & $\begin{array}{c}\text { Help Seeking } \\
\text { Effort Regulation } \\
\text { Time Management }\end{array}$ & $\begin{array}{l}\text { "When I can't understand the material in this course, I } \\
\text { ask another student in this class for help. I try to get } \\
\text { help from other students, when doing an assignment." }\end{array}$ \\
\hline $\begin{array}{l}\text { Regulation } \\
\text { of Context }\end{array}$ & & Peer Learning & $\begin{array}{l}\text { "When studying for this course, I often try to explain } \\
\text { the material to a classmate or friend. When learning } \\
\text { course material, I try to explain that material to a friend." }\end{array}$ \\
\hline
\end{tabular}

ing of new psychology students. Regression analysis was conducted to answer the second study question, and to determine the correlation and functional relationships between aspects of self-regulated learning and Student Achievement Indexes (IPS). The analysis process was conducted using the SPSS Statistic 22.0 software.

\section{Results}

The Results section is divided into two discussions. The first discussion will explain the potential for the ability to engage in self-regulated learning; beginning with the ability to regulate cognition, motivation and affection, behavior and environmental context. The second discussion will explain how the potential for self-regulated learning has a role in academic achievement, which in this study uses the Semester 1 IPS.

Table 2 shows the descriptive statistical results of the ability for self-regulated learning, depicted via the MSLQ measurement instrument. Around 50\% of par- ticipants were above average in perceiving their selfregulatory ability in learning. This shows that just half of the new students had positive learning experiences and positive expectations influencing their perception about self regulated learning ability (Betancourt, 2018; Dell'Angelo, 2016). It was only in the aspect of Internal Goal Motivation where nearly all participants perceived their ability to be above average $(70 \%)$.

Regression analysis was conducted to see whether there was a functional relationship between each aspect of the MSLQ measurement instrument and the IPS of new students (Table 3). Results from the regression analysis indicated that there is a significant functional relationship with the aspect of effort regulation $\left(t(93)=-2.138, p=.035 ; r^{2}=.047\right)$, so that the linear equation formed was $I P S=3.955-0.025$ with effort regulation (ER) . Besides this, a significant functional relationship was also found with the aspect of help seeking $\left(t(93)=-2.400, p=.018 ; r^{2}=.058\right)$, so that the linear similarity formed was $I P S=3.968-0.021$ with help seeking (HS). The eleven other aspects did not indicate the existence of any significant relationship 
Table 2

Descriptive Analysis of Self Regulated Learning for New Students of the Psychology Course $(n=95)$

\begin{tabular}{|c|c|c|c|c|c|c|c|}
\hline Regulation & Mean & $\begin{array}{l}\text { Standard } \\
\text { Deviation }\end{array}$ & Aspects & Mean & $\begin{array}{l}\text { Standard } \\
\text { Deviation }\end{array}$ & $\begin{array}{c}\text { Below } \\
\text { Average }\end{array}$ & $\begin{array}{r}\text { Above } \\
\text { Average }\end{array}$ \\
\hline $\begin{array}{l}\text { Regulation of } \\
\text { Cognition } \\
\text { (Part of Learning }\end{array}$ & 137.021 & 18.477 & $\begin{array}{c}\text { Cognitive Strategies } \\
\text { (Rehearsal, } \\
\text { Elaboration,Organization) }\end{array}$ & 61.69 & 10.002 & $53.7 \%$ & $46.4 \%$ \\
\hline \multirow[t]{2}{*}{ Strategies Scales) } & & & $\begin{array}{c}\text { Meta-cognitive Self- } \\
\text { regulation }\end{array}$ & 56.38 & 7.201 & $41 \%$ & $58.9 \%$ \\
\hline & & & Critical Thinking & 18.95 & 3.378 & $55.8 \%$ & $44.2 \%$ \\
\hline Regulation of & 82.789 & 8.663 & Effort Regulation & 19.43 & 2.616 & $35.8 \%$ & $64.2 \%$ \\
\hline Behavior & & & Help Seeking & 23.17 & 3.389 & $54.7 \%$ & $45.2 \%$ \\
\hline (Part of Learning & & & Time \& Study & 40.19 & 4.727 & $42.1 \%$ & $57.9 \%$ \\
\hline Strategies Scales) & & & Environment & & & & \\
\hline $\begin{array}{l}\text { Regulation of } \\
\text { Context } \\
\text { (Part of Learning } \\
\text { Strategies Scales) }\end{array}$ & 54.821 & 5.964 & PeerLearning & 14.63 & 2.634 & $60 \%$ & $40 \%$ \\
\hline Regulation of & 171.652 & 18.148 & Intrinsic Goal Motivation & 22.51 & 2.767 & $26.3 \%$ & $73.7 \%$ \\
\hline Motivation \& & & & Extrinsic Goal Motivation & 31.88 & 5.287 & $46.5 \%$ & $53.7 \%$ \\
\hline Affect & & & Task Value & 31.58 & 4.326 & $49.4 \%$ & $50.5 \%$ \\
\hline (Motivation & & & Control Beliefs & 23.69 & 2.783 & $55.8 \%$ & $44.3 \%$ \\
\hline \multirow[t]{2}{*}{ Scales) } & & & Self-efficacy & 38.46 & 6.421 & $49.4 \%$ & $50.5 \%$ \\
\hline & & & $\begin{array}{l}\text { Affective Component } \\
\text { (TestAnxiety) }\end{array}$ & 23.53 & 5.461 & $47.4 \%$ & $52.7 \%$ \\
\hline
\end{tabular}

Table 3

Regression Analysis of Each Aspect of Self-regulated Learning in Predicting IPS $(n=95)$

\begin{tabular}{lccccccr}
\hline Aspects & $B$ & $S E B$ & $\beta$ & $t(93)$ & $p$ & $F$ & $R^{2}$ \\
\hline Cognitive Strategies & -0.001 & 0.003 & -0.047 & -0.458 & 0.648 & 0.210 & 0.002 \\
Meta-cognitive Self-regulation & -0.005 & 0.004 & -0.110 & -1.067 & 0.289 & 1.138 & 0.012 \\
Critical Thinking & -0.014 & 0.009 & -0.159 & -1.552 & 0.124 & 2.408 & 0.025 \\
Intrinsic Goal Motivation & -0.014 & 0.011 & -0.132 & -1.285 & 0.202 & 1.651 & 0.017 \\
Extrinsic Goal Motivation & -0.001 & 0.006 & -0.025 & -0.236 & 0.814 & 0.056 & 0.001 \\
Task Value & 0.001 & 0.007 & 0.012 & 0.112 & 0.911 & 0.013 & 0.000 \\
Control Beliefs & 0.004 & 0.011 & 0.038 & 0.370 & 0.712 & 0.137 & 0.001 \\
Self-efficacy & 0.003 & 0.005 & 0.075 & 0.723 & 0.472 & 0.522 & 0.006 \\
Affective Component (Test Anxiety) & 0.001 & 0.006 & 0.016 & 0.154 & 0.878 & 0.024 & 0.000 \\
Effort Regulation & -0.025 & 0.011 & -0.216 & -2.138 & $0.035^{*}$ & 4.573 & 0.047 \\
Help Seeking & -0.021 & 0.009 & -0.241 & -2.400 & $0.018^{*}$ & 5.758 & 0.058 \\
Time \& Study Environment & -0.002 & 0.007 & -0.038 & -0.366 & 0.715 & 0.134 & 0.001 \\
Peer Learning & -0.007 & 0.012 & -0.062 & -0.596 & 0.553 & 0.355 & 0.004 \\
\hline Noer & & & & & & &
\end{tabular}

Note. $* p<.05$ (significant predictive correlation)

with the IPS.

\section{Discussion}

The principle goal of this study was to show the extent of the potential ability for self-regulated learning of new students in the psychology course. The initial finding was that many of the new psychology students (70\%) had a high potential for the ability for motivation regulation, that is, in the aspect of internal goal moti- vation. This high potential would support the students in controlling their learning processes. The learning goals which new students determine are based more upon desires, needs and self-development. This would support students through the forethought phase of the processes of self-regulated learning (Pintrich, 2004). The internally sourced determination of goals and motivation would have a positive influence on the choices of good learning strategies, learning effort, and, indirectly, on academic grades obtained by the individual (Kusurkar, Ten Cate, Vos, Westers, \& Croiset, 2013). 
The second finding, that is, the potential which tends only somewhat to be optimized by new psychology students, is the potential to regulate the environmental context, that is, in the aspect of peer learning. The aspect of peer learning relates to how effectively students utilize their peers to assist them in the learning process. In that process, new students apparently were still focused upon independent learning, and it was still only very few who saw learning together with friends as a strategy which could support the learning process. Learning with peers can be one of the variations for learning, which will support greater flexibility in the monitoring and control phases of the self-regulated learning cycle (Pintrich, 2004).

The second goal of this study was to determine how each aspect of self-regulated learning plays a role in the Index of Student Achievement (IPS). The academic achievement selected by the authors was the Semester 1 IPS, because it could explain at least half of the variations in the educational research model (Bloom, 1976, as cited in Bacon \& Bean, 2006). Based upon the results of regression analysis, the authors discovered that the aspect of help seeking and effort regulation, which form a part of resource management strategy, could significantly predict the IPS of new students. One of the functions of a resource management strategy is to regulate the behavior of the student, during the learning process. Based upon Credé and Phillips' meta-analysis research into the MSLQ, the aspect of effort regulation has been proven to have a fairly strong (moderate to strong) correlation with academic grades, and is also a predictor of academic performance, such as in examination results, learning skills and learning habits (Credé \& Phillips, 2011). The help seeking aspect can be an effective strategy in learning, when a student perceives that, with the help of others, he or she will obtain commensurate advantage, so that this aspect can be a mediator in attaining the desired achievement (Roussel, Elliot, \& Feltman, 2011).

The ability to predict these two aspects (help seeking and effort regulation) are only slightly related, so that these two aspects require other variables to be able to predict the IPS more accurately. One of the variables which can be supportive is values. The intended concept of values covers intrinsic goals, extrinsic goals, task values (Yusri, Rahimi, \& Wah, 2011; Zimmerman, Bandura, \& Martinez-Pons, 1992).The study conducted by Yusri et al. (2011) found that there was a significant correlation between values, regarding certain subjects, and the resource management strategy. The higher the values of the student, the more effective was the use of the resource management strategy. Yang,
M. C. Chen, and Chens' study stated that prior knowledge influences the use of the resource management strategy, which will later have an impact on the overall academic performance of the student. (Yang, Chen, $\&$ Chen, 2018). Besides that of the student him or herself, the roles of the lecturers and the orientation period in giving direction and expectations in autonomysupportive learning is very large, for a new student to be able to adopt and absorb self-regulated learning behavior (Sierens, Vansteenkiste, Goossens, Soenens, \& Dochy, 2009). Learning facilities, communication skills, and even parental support can be variables influencing academic achievement (Singh, Malik, \& Singh, 2016).

To illustrate the nature of the self-regulated learning process for new psychology students, the authors utilized the approach of analysis based upon the data which had been collected. The initial phase in commencing the self-regulated learning process was to determine the goal of the learning process. New students determine this goal based upon their internal resources, and from this also they regulate their own motivation to continue learning and produce a good academic performance. Although this is so, the existence of this internal motivation does not spontaneously eradicate the worries of the students when facing an examination (one half of the students were anxious when facing an examination), and the students still need reinforcement, in order to be more confident that they can control their learning performances (a large proportion of students were below average on the aspect of belief control).

Throughout the learning process, new students used various common cognitive strategies, such as rehearsal, organization, and elaboration. If analyzed item per item, the students tend more to use elaboration strategy, such as by making summaries, and by seeking examples from the given material. Even meta-cognitive strategies are still used, inter-alia reviewing his or her own understanding of explanations given in class, whilst the strategies still only rarely used are peer learning and critical thinking. The learning strategies chosen were oriented towards the individual, and a large number of the students were uncritical in accepting, processing and evaluating all material and information conveyed in class. In relation to this, the aspects of effort regulation and help seeking will assist new students to attain a more optimal IPS. For this reason, it is important to create a learning environment conducive to the students not being nervous in seeking assistance, and a supportive learning environment to increase the efforts they deploy in every step of the learning process. 


\section{Limitations}

The limitations of this study are those of the scope of the study. It would be more representative if this depiction of self-regulated learning as regards new students of psychology courses was conducted in a number of universities having psychology faculties. Such follow-up study could conduct cross sectional or longitudinal studies, to examine the development of ability regarding self-regulated learning for psychology course students, from year to year. In follow-up studies, it could even be recommended that multiple regression analysis be conducted to see the functional relationships between combinations of the aspects of self-regulation on the MSLQ measurement instrument. It would even be interesting to conduct studies seeking a model, based upon the MSLQ measurement instrument.

\section{Conclusion}

In this study, it was found that there are only two aspects of self-regulated learning which influence the IPS of psychology students, these being effort regulation and help seeking. These two things can be reinforced with support external to the student, that is, from the surrounding environment. Forming learning groups, facilitating pleasant means and infrastructure for learning, and an appreciative teaching team are several ways to strengthen effort regulation.

One of the features of Indonesian culture is that it is collective, and basically this will support the development of help seeking behavior. As well, the culture of showing respect to older people in Indonesia is quite strong, so that there is willingness on the part of students to seek help from seniors, or lecturers. For this to occur, it is necessary for an open academic climate to be created, to create opportunities for students and lecturers to interact, with there being discussions in class and a willingness from lecturers to allocate particular times to assist students.

\section{Acknowledgement}

This article was presented at the Temu Ilmiah Nasional Himpunan Psikologi Indonesia (National Scientific Meeting of the Indonesian Psychological Association), of September, 2018. The article has been revised on the basis of the review conducted by a reviewer at the Klinik Penulisan Artikel Ilmiah (Writing Clinic for Scientific Articles), conducted by Kemenristekdikti (the Indonesian Ministry of Research, Technology, and Higher Education), in October, 2018.

\section{References}

Bacon, D. R., \& Bean, B. (2006). GPA in research studies: An invaluable but neglected opportunity. Journal of Marketing Education, 28(1), 35-42. https:// doi.org/10.1177/ 0273475305284638

Betancourt, J. R. (2018). Perception is reality, and reality drives perception: No time to celebrate yet. Journal of General Internal Medicine, 33(3), 241-242. https://doi.org/10.1007/s11606-017-4263-z

Chemers, M. M., Hu, L.-t., \& Garcia, B. F. (2001). Academic self-efficacy and first year college student performance and adjustment. Journal of Educational Psychology, 93(1), 55-64. https://doi.org/10.1037 /0022-0663.93.1.55

Clemons, T. L. (2008). Underachieving gifted students: A social cognitive model. National Research Center on the Gifted and Talented.

Credé, M., \& Phillips, L. A. (2011). A meta-analytic review of the motivated strategies for learning questionnaire. Learning and Individual Differences, 21(4), 337-346. https://doi.org/10.1016/j.lindif.20 11.03 .002

Dell'Angelo, T. (2016). The power of perception: Mediating the impact of poverty on student achievement. Education and Urban Society, 48(3), 245-261. https://doi.org/10.1177/ 0013124514531042

Dörrenbächer, L., \& Perels, F. (2016). Self-regulated learning profiles in college students: Their relationship to achievement, personality, and the effectiveness of an intervention to foster self-regulated learning. Learning and Individual Differences, 51, 229241. https://doi.org/10.1016/j.lindif.2016.09.015

Duncan, T. G., \& McKeachie, W. J. (2005). The making of the motivated strategies for learning questionnaire. Educational Psychologists, 40(2), 117128. https://doi.org/10.1207/s15326985ep4002_6

Fabriz, S., Ewijk, C. D.-v., Poarch, G., \& Büttner, G. (2014). Fostering self-monitoring of university students by means of a standardized learning journalA longitudinal study with process analyses. European Journal of Psychology of Education, 29(2), 239255. https://doi.org/10.1007/s10212-013-0196-z

Fasikhah, S. S., \& Fatimah, S. (2013). Self-regulated learning (SRL) dalam meningkatkan prestasi akademik pada mahasiswa. Jurnal Ilmiah Psikologi Terapan, $1(1), 145-155$.

Garrett, A. J., Mazzocco, M. M., \& Baker, L. (2006). Development of the meta-cognitive skills of prediction and evaluation in children with or without math ability. Learning Disabilities, 21(2), 77-88.

Irfan, M., \& Suprapti, V. (2014). Hubungan self-effi- 
cacy dengan penyesuaian diri terhadap perguruan tinggi pada mahasiswa baru Fakultas Psikologi Universitas Airlangga. Jurnal Psikologi Pendidikan dan Perkembangan, 3(3), 172-178.

Komarraju, M., \& Nadler, D. (2013). Self-efficacy and academic achievement: Why do implicit beliefs, goals, and effort regulation, matter? Learning and Individual Differences, 25, 67-72.

Kusurkar, R. A., Ten Cate, T. J., Vos, C. M. P., Westers, P., \& Croiset, G. (2013). How motivation affects academic performance: A structural equation modelling analysis. Advances in Health Sciences Education, 18(1), 57-69. https://doi.org/10.1007/s10459012-9354-3

Özsoy, G., \& Ataman, A. (2009). The effect of metacognitive strategy training on mathematical problemsolving achievement. International Electronic Journal of Elementary Education, 1(2), 68-83.

Pintrich, P. R. (1991). A manual for the use of the Motivated Strategies for Learning Questionnaire (MSLQ). Retrieved from ERIC Institute of Education Sciences at https://eric.ed.gov/?id=ED338122

Pintrich, P. R. (2000). The role of goal orientation in self-regulated learning. Handbook of Self-Regulation, 451-502. https://doi.org/10.1016/B978-0121 09890-2/50043-3

Pintrich, P. R. (2004). A conceptual framework for assessing motivation and self-regulated learning in college students. Educational Psychology Review, 16(4), 385-407.

Rana, R. A., \& Mahmood, N. (2010). The relationship between test anxiety and academic achievement. Bulletin of Education and Research, 32(2), 63-74. Retrieved from https://ssrn.com/abstract $=2362291$

Roussel, P., Elliot, A. J., \& Feltman, R. (2011). The influence of achievement goals and social goals on help-seeking from peers, in an academic context. Learning and Instruction, 21(3), 394-402. https:// doi.org/10.1016/j.learninstruc.2010.05.003

Schneider, M., \& Preckel, F. (2017). Variables associated with achievement in higher education: A sys- tematic review of meta-analyses. Psychological Bulletin, 143(6), 565-600. https://doi.org/10.1037/bul 0000098

Sierens, E., Vansteenkiste, M., Goossens, L., Soenens, B., \& Dochy, R. (2009). The synergistic relationship of perceived autonomy support and structure, in the prediction of self-regulated learning. British Journal of Educational Psychology, 79, 57-68.

Singh, S. P., Malik, S., \& Singh, P. (2016). Factors affecting academic performance of students. ParipexIndian Journal of Research, 5(4), 176-178.

Valentine, J. C., DuBois, D. L., \& Cooper, H. (2004). The relation between self-belief and academic achievement: A meta-analytic review. Journal Educational Psychologist, 29(2), 111-133. https://doi.org/ 10.1207/s15326985ep3902_3

Yang, T.-C., Chen, M. C., \& Chen, S. Y. (2018). The influences of self-regulated learning support and prior knowledge on improving learning performance. Computers \& Education, 126, 37-52. https://doi.org/ 10.1016/j.compedu.2018.06.025

Yusri, G., Rahimi, N. M., \& Wah, W. H. (2011). Value and resource management strategies among students of an 'Arabic as a third language' course. Procedia - Social and Behavioral Sciences, 29, 1635-1644. https://doi.org/10.1016/j.sbspro.2011.11.406

Zajacova, A., Lynch, S. M., \& Espenshade, T. J., (2005). Self-efficacy, stress, and academic success in college. Research in Higher Education, 46(6), 677-706. https://doi.org/10.1007/s11162-004-4139-z

Zimmerman, B. J., Bandura, A., \& Martinez-Pons, M. (1992). Self-motivation for academic attainment: The role of self-efficacy beliefs and personal goal setting. American Educational Research Journal, 29(3), 663-676. https://doi.org/10.3102/00028312 029003663

Zimmerman, B. J., \& Kitsantas, A. (2005). Homework practice and academic achievement. The mediating role of self-efficacy and perceived responsibility beliefs. Contemporary Educational Psychology, 30, 397417. https://doi.org/10.1016/j.cedpsych.2005.05.003 